УдК. $616-008.9-053.3$

\title{
Хвороба Помпе
}

\section{Фвиридова Н.К.}

д.мед.н., професор, завідувач кафедри неврології і рефлексотерапії Національної медичної академії післядипломної освіти імені П.Л. Шупика

плізарова О.В.

інтерн кафедри неврології і рефлексотерапії Національної медичної академії післядипломної освіти імені П.Л. Шупика

- Свистун В.Ю.

клінічний ординатор кафедри неврології і рефлексотерапії Національної медичної академії післядипломної освіти імені П.Л. Шупика

\section{Резюме}

Захворювання Помпе є рідкісною, прогресуючою хворобою, в основі патогенезу якої лежить надмірне накопичення глікогену лізосомами в результаті мутації гену GAA і втрати активності ферменту кислої $\alpha$-глюкозидази. Переважне накопичення глікогену відмічено в поперечно-посмугованих м'язах, але в різному ступені може виявлятися і в інших органах і тканинах, включаючи серцевий м'яз, печінку, нервову систему. Тип успадкування - аутосомнорецесивний. У клінічній практиці виявлення характерних симптомів дозволяють своєчасно запідозрити хворобу Помпе. Достатня інформованість та настороженість лікаря щодо хвороби Помпе, при сукупності характерних симптомів полегшує діагностику. РТ в Т1-режимі дозволяє легко оцінити трофіку м'язів і виявити специфічні області фіброзно-жирової дегенерації, що характерно для м'язової дистрофії. Дослідження м'язового біоптату при хворобі Помпе виявляє вакуольну міопатію лізосомальної природи при визначенні активності кислої фосфатази, при гістоферментативному дослідженні, а також накопичення глікогену. В основі біохімічної діагностики хвороби Помпе лежить дослідження активності ферменту GAA за допомогою природних або синтетичних субстратів в кислому середовищі. Сучасні методи молекулярної біології дозволяють передбачити ступінь тяжкості хворо- би, яка корелює із залишковим рівнем активності ферменту. Рекомендована пожиттєва ферментозамісна терапія рекомбінантної людської кислої $\alpha$-глюкозидази пацієнтам з підтвердженим діагнозом хвороби Помпе. Ферментна замісна терапія дозволяє зберегти життя пацієнтам з хворобою Помпе, покращує її якість та уповільнює прогресування хвороби. Ранній початок терапії дуже важливий, тому що дозволяє домогтися кращих клінічних результатів. Доведено, що застосування ферментної замісної терапії при дитячій формі хвороби зменшує ризик смерті на 99\%, а ризик смерті або необхідності в інвазивній вентиляції легенів - на 92\%. При наявності підтвердженого діагнозу хвороби Помпе, незалежно від віку пацієнта, патогенетична терапія алглюкозидазой альфа повинна бути ініційована негайно.

Ключові слова: хвороба Помпе, дефіцит кислої мальтази (AMD), порушення накопичення глікогену (GSD) типу II, глікогеноз типу II, дефіцит альфаглюкозидази.

Захворювання Помпе є рідкісною, прогресуючою хворобою, в основі патогенезу якої лежить надмірне накопичення глікогену лізосомами в результаті мутації гену GAA і втрати активності ферменту кислої а-глюкозидази. Переважне накопичення глікогену відмічено в поперечно-посмугованих м'язах, але в різному ступені може виявлятися і в інших органах і тканинах, включаючи серцевий м'яз, печінку, нервову систему. Тип успадкування аутосомно-рецесивний. Ген GAA, кодуючий кислу а-глюкозидазу, локалізований на довгому плечі 17 хромосоми (17q25.2-q25.3) [1]. Виявлено більше 350 мутацій [2]. Хвороба Помпе була названа на честь голландського патологоанатома Дж. Помпе, який вперше у 1932 році описав летальний випадок дівчинки 7 місяців з мультисистемним ураженням: кардіоміопатією, дихальною та печінковою недостатністю в поєднанні з прогресуючою генералізованою м'язовою слабкістю $[8,9]$ 
Поширеність хвороби Помпе залежить від етнічної приналежності та географії. Швидко прогресуюча інфантильна форма має приблизну частоту 1:138 000 серед осіб кавказького походження [15], 1:50 000 серед осіб китайського походження [10], i 1:14 000 серед осіб африканського походження [8], також було зазначено високу поширеність захворювання в арабських популяціях. Сьогодні вважається, що сумарна частота хвороби Помпе складає 1:40000 [11]. Розвиток скринінгу новонароджених для хвороби Помпе дає ще один шанс оцінити захворюваність. Перший пілотний проект розпочав у Тайвані (вимірювання активності GAA у сухій краплі крові (DBS) з метою подальшого вивчення активності ферменту альфаL-ідуронидази). Частота випадків інфантильної форми у Тайвані становить 1 на 52000 новонароджених [16].

За етіологією генетичний дефект при хворобі Помпе проявляється недостатністю ферменту кислої альфа-глюкозидази, який відноситься до групи лізосомальних гідролаз. Ген GAA, що кодує a-глюкозидазу, локалізована на довгому плечі 17 хромосоми (17q25.2-q25.3), складається 3 20 екзонів і має розмір 20 Кб. Сьогодні ідентифіковано більш 350 мутацій, які зафіксовано в Помпе центрі університету ім. Еразма в Роттердамі. [2]. У різних етнічних групах зустрічаються декілька найрізноманітніших мутацій, включаючи мутації сплайсингу -13T>G у пацієнтів з Кавказу, мутація р.R854X у афро-американців та мутація p.D645E у пацієнтів з Китаю та Тайваню [10]. Хоча деякі мутації гена GAA зустрічаються переважно в певній етнічній групі для більшості популяцій відсутні так звані founder-мутації, що становлять значну частку всіх мутацій популяції і тому доцільні для прицільного виявлення. Мутації гена GAA призводять до зниження або повної відсутності активності кислої альфа-глюкозидази. Захворювання моногенне, успадковується за аутосомно-рецесивним типом.

При аналізі патофізіологічного аспекту Хвороби Помпе встановлено, що мутації в двох копіях гена GAA, що кодує лізосомальний ензим GAA, відповідальний за деградацію глікогену в лізосомах, призводять до різної ступеня дефіциту ензима. Інфантильна форма хвороби Помпе розвивається при значному зниженні або при повній відсутності активності альфа-глюкозидази, хвороба Помпе з пізнім початком - при менш виражених дефіцитах кислої альфа-глюкозидази (обумовлено легкими мутаціями гену GAA) $[5,11]$.

В нормі глікоген накопичується в скелетних м’язах і печінці. Відкладення або утилізація глікогену залежать від потреби організму в глюкозі. Біохімічні перетворення глікогену в печінці сприяють підтриманню нормального рівня глюкози в крові. У скелетних м'язах при метаболізмі глікогену утворюється глюкозо-6-фосфат, що бере участь у процесі окислення та виробництва енергії, необхідної для нормальної роботи м’язів (їх скорочен- ня і розслаблення). Білок-попередник масою 110 кДа синтезується в ендоплазматичному ретикулумі і реплікується під контролем білківшаперонов. Після завершення процесу глікозилювання в апараті Гольджі проміжний білок переноситься в лізосоми, де відбувається його розпізнавання за участю катіонно-залежних рецепторів манози-6-фосфату (CI-MPR) і протеоліз на 2 ізоформи масою 76 і 90 кДа. Функція білка GAA полягає в розщепленні в кислому середовищі глікозидних зв'язків $\alpha-1,4$ і 1,6 глікогену з утворенням глюкози, яка потім активно транспортується через мембрану лізосом за допомогою специфічного переносника. Мутантні білки GAA руйнуються в цитоплазмі, в результаті чого порушується метаболізм глікогену і відбувається його накопичення в лізосомах. Клінічні прояви в основному визначаються патологічним накопиченням глікогену, хоча патогенез захворювання цим не вичерпується [12].

При хворобі Помпе, незалежно від форми, глікоген може накопичуватися практично в будьяких тканинах, але при цьому є переважне скупчення глікогену в різних органах і тканинах, яке вже залежить від форми хвороби. Так, при інфантильній формі хвороби Помпе глікоген накопичується в скелетних м'язах, печінці, міокарді, м'язах язика. Рідше аномальні відкладення глікогену можуть зустрічатися в м'язовому шарі судинної стінки, визначаючи розвиток аневризм і мальформацій, а також - в клітинах центральної і периферичної нервової системи [11]. При хворобі Помпе 3 пізнім початком найбільше страждають скелетні м'язи, в той час як ураження інших органів і тканин зустрічається значно рідше $[11,13]$. На пізніх стадіях Хвороби Помпе з пізнім початком спостерігається зниження слуху, тазові порушення, а також виявляються внутрішньомозкові судинні мальформації [14].

Класична інфантильна форма та хвороба Помпе з пізнім початком - дві найпоширеніші форми розладу. Інфантильна форма хвороби Помпе маніфестує в період новонародженості або в ранньому дитячому віці. Ця форма характеризується важким прогресуючим перебігом і швидким розвитком поліорганної патології - м'язової гіпотонії, серцевої недостатності в результаті гіпертрофічної кардіоміопатії, дихальної недостатності на тлі слабкості діафрагми і міжреберних м'язів, порушень харчування через слабкість лицьової мускулатури і збільшення розмірів язика та печінки. Смерть при інфантильній формі без своєчасного лікування найчастіше настає на першому році життя від серцево-дихальної недостатності [5]. Хвороба Помпе, що має пізній початок, відрізняється від попередньої форми не такими виразними клінічними проявами та перебігом, відсутністю поліорганної патології та більш пізніми ускладненнями з боку дихальної системи в результаті слабкості м'язів діафрагми і міжреберної мускулатури. Доведено, що пацієнти 
гинуть від дихальної недостатності та інфекційних легеневих ускладнень. Смертність пацієнтів при пізній формі залежить від моменту початку і подальшого характеру перебігу хвороби і може наступити в дитинстві, юнацькому, дорослому або похилому віці. Ранні прояви хвороби Помпе у дітей та дорослих залежать від віку, в якому вони маніфестували. Діти молодшого віку можуть не навчитися ходити, вони частіше, ніж інші діти, спотикаються або падають при ходьбі. У дорослих першим проявом захворювання можуть бути труднощі при вставанні з положення сидячи. Поступово з'являється прогресування симптомів та поява порушень з боку дихальної системи: задишка після фізичного навантаження, або вранішній головний біль (внаслідок проблем з диханням протягом ночі) [6]. Класична інфантильна форма та пізня форма хвороби Помпе, як правило, співвідносяться з активністю $\alpha$-глюкозидази, яка у дітей у віці до 1 років становить менше 1\% нормальної активності, у молоді - менш ніж 10\%, у дорослих - менше 40\%. Частота випадків захворювання Помпе оцінюється в 1 на 57000 [7].

При спробі встановити загальну термінологію, хворобу Помпе класифікували наступним чином: 1) класична інфантильна форма хвороби Помпе; 2) некласична інфантильна форма хвороби Помпе; 3) пізня форма хвороби Помпе

\section{Класична інфантильна форма хвороби Помпе}

Це найбільш агресивна форма хвороби, яка проявляється в перші 6 місяців життя. Виражена м’язова слабкість (міопатія) є найбільш типовою ознакою. У дітей з хворобою Помпе знижений м'язовий тонус (гіпотонія), вони виглядають як «жабенята», не можуть підняти голову, повільно вивчають моторні навички, іноді набуті навички у дітей з хворобою Помпе можуть втрачатися. Іноді хворі можуть так і не навчитися сидіти, повзати або стояти. М'язова слабкість швидко прогресує. Процеси дихання, смоктання і ковтання для хворих $€$ важкими. При фізикальному огляді відзначається кардіомегалія, гепатомегалія, макроглосія. Хворі діти повільно набирають вагу, значно відстають в фізичному розвитку від однолітків. Психічний розвиток не порушений. Зростаюча м'язова слабкість веде до серцево-легеневої недостатності. Якщо не розпочати лікування, то діти 3 хворобою Помпе гинуть ще на першому році життя.

При класичній інфантильній формі хвороби Помпе мати скаржиться на те, що дитина погано набирає вагу, втомлюється під час годування, малоактивна, відстає в розвитку, завжди тримає рот відкритим, язик збільшений, часто бувають запори, іноді блювота. Перші ознаки і симптоми хвороби з'являються вже на 2-3 місяці життя. При огляді у педіатра звертає на себе увагу м'язова гіпотонія і прогресуюча м'язова слабкість. Обличчя дитини набуває характерного вигляду: рот відкритий, порожнина рота заповнена збіль- шеним язиком (у 1/3 немовлят), міміка ослаблена. Подальший огляд виявляє щільність м'язів, виявляються ознаки дихальної та серцевої недостатності: блідість шкіри, акроціаноз, гіпергідроз, прискорене дихання, участь допоміжної мускулатури в акті дихання, деформація грудної клітини за типом «серцевого горба», розширення меж відносної серцевої тупості, ослаблення периферичної пульсації, гепатомегалія, периферичні набряки. Аускультативно в легенях дихання жорстке, ослаблення дихання зліва, тахіпное; тони серця глухі, систолічний шум над всією поверхнею серця, порушення ритму серця (тахікардія, брадикардія, шлуночкова аритмія). При більш пізньому дебюті інфантильної форми - в анамнезі часті респіраторні інфекції.

Неврологічний огляд виявляє виражену затримку фізичного розвитку у вигляді порушення формування моторних навичок: знижена спонтанна і довільна рухова активність, дитина не тримає голову, не перевертається самостійно, не сидить. Слабкість проксимальних м'язів в положенні лежачи надає дитині характерну «позу жаби», при піднятті дитини за руки голова відкидається назад. Характерний синдром «млявої дитини». Також може спостерігатися гіпертрофія і пальпаторная щільність м'язів нижніх кінцівок. Сухожилкові рефлекси в дебюті можуть бути збережені, але в міру прогресування захворювання згасають. Неспецифічні прояви мають вигляд загального нездужання, дратівливості дитини, підвищеної пітливості, блювоти і запорів. Рідкісним, проявом патології є зниження слуху. В результаті порушення резорбції спинномозкової рідини розвивається гідроцефалія $[4,5,6,17,18]$.

\section{Некласична інфантильна форма хвороби Помпе}

Проявляється до першого року життя. Характеризується пізнім розвитком моторних навичок і прогресуючою м'язовою слабкістю. Кардіомегалія також може спостерігатися при цій формі, що може бути причиною серцевої недостатності. Слабкість м'язів в подальшому веде до значних ускладнень з боку дихальної системи і якщо не лікувати, то діти $з$ такою формою хвороби Помпе гинуть в ранньому дитячому віці. Швидкість прогресування симптомів не настільки значна як при класичній формі [17].

\section{Хвороба Помпе з пізнім початком}

Пізня форма хвороби Помпе характеризується повільно-прогресуючим перебігом з переважним ураженням скелетних м'язів, відсутністю поліорганної патології і більш пізніми ускладненнями з боку дихальної системи в результаті слабкості м'язів діафрагми і міжреберної мускулатури. Зазвичай пацієнти гинуть від дихальної недостатності і інфекційних легеневих ускладнень. Смертність від хвороби Помпе з пізнім початком корелює 3 часом настання перших клінічних проявів [7]. 
Слабкість м'язів кінцівок є основною скаргою пацієнтів з пізньою формою, яка виявляється у 93\% випадків $[13,19]$. У більшості випадків максимальна слабкість стосується параспінальних м'язів і м'язів передньої стінки живота, м'язів проксимальних відділів нижніх кінцівок та м'язів плечового відділу. Слабкість проксимальних відділів кінцівок переважає над слабкістю в дистальних відділах. Хворі також скаржаться на зміну ходи (іноді по типу «качиної»), швидке стомлення при ходьбі, неможливість сісти або встати з положення лежачи без допомоги рук, непереносимість фізичних навантажень, головний біль, задишку, утруднення дихання, відчуття неповного вдиху, збільшення язику, помірні хронічні болі в м'язах. В подальшому у дитини розвивається порушення постави, з'являється гіперлордоз, сколіоз, хода нагадує «качину». М'язи ніг і тазового поясу уражаються більше, ніж м'язи плечового відділу. У дітей часто розвивається регіональна псевдогіпертрофія м'язів спини, а також симптом ригідного хребта. Прогресування хвороби призводить до порушень дихання, найчастіше у формі нічної гіповентиляції, частих інфекційних захворювань та аспіраційної пневмонії. Дитина може пред'являти скарги на головний біль, в поведінці відзначається швидка стомлюваність і зниження стійкості до звичних навантажень. Слабкість мімічних м'язів, помірний птоз (часто асиметричний) збільшення язику, зниження сухожильних рефлексів також повинні насторожити в плані наявності у дитини захворювання. При пізній формі, на відміну від дитячої форми, кардіоміопатія зустрічається значно рідше.

На ранніх стадіях хвороби зміни в м'язах можуть проявлятися тільки ходою по типу «качиної ходи» 3 гіперлордозом поперекового відділу. Слабкість м'язів плечового поясу найчастіше виявляється при проведенні діагностичних тестів. Досить часто слабкість і атрофії м'язів плечового поясу можуть бути асиметричними, що може проявлятися у вигляді крилоподібної лопатки тільки з одного боку або значної асиметрії даного симптому.

Параспінальні м’язи та м'язи передньої стінки живота можуть уражатися на самих ранніх стадіях хвороби, що призводить до швидкої стомлюваності, зниження толерантності до стандартних фізичних навантажень як на ранніх, так і розгорнутих стадіях хвороби. Важливим є виявлення порушення дихальної функції внаслідок слабкості м'язів діафрагми і міжреберних м'язів $[7,11,13,19]$.

\section{Діагностика}

У клінічній практиці виявлення характерних симптомів дозволяють своєчасно запідозрити хворобу Помпе. Достатня інформованість та настороженість лікаря щодо хвороби Помпе, при сукупності характерних симптомів полегшує діагностику.
Жодне зі стандартних клінічних досліджень, які використовуються в діагностиці нервовом'язових хвороб, не є абсолютним при хворобі Помпе. Електроміографія (ЕМГ) голчастими електродами виявляє ознаки первинно-м'язового рівня ураження. Рівень КФК підвищується в 2-5 разів, але може бути і нормальним. Виявлення на електрокардіограмі (ЕКГ) збільшення амплітуди QRS, скорочення інтервалу P-Q змушує припустити наявність кардіоміопатії. Ехокардіографія виявляє розширення лівого шлуночка. Як і при всіх інших міопатіях, зниження форсованої життєвої ємності легень (ФЖЕЛ) при спірометрії, а також сили діафрагми, що оцінюється більш тонкими методами, вказує на рестриктивну дихальну недостатність. При цьому показники ФЖЄЛ в положенні лежачи гірше, ніж в положенні сидячи [20].

\section{Магнітно-резонансна томографія (МРТ)}

скелетних м'язів - $є$ інформативним методом дослідження при хворобі Помпе. МРТ в Т1-режимі дозволяє легко оцінити трофіку м'язів і виявити специфічні області фіброзно-жирової дегенерації, що характерно для м'язової дистрофії. Дослідження R.Y. Carlier і співавт. [21] показало, що при підозрі на хворобу Помпе показана МРТ всього тіла, тому що існує характерні ураження певних груп м'язів , включаючи ураження язика і аксіальної мускулатури, а також м'язів, що утримують лопатку, і зубчастих м'язів, великих м'язів стегон і сідничних м'язів. Накопичення глікогену в м'язах було досліджено при спектроскопії ядерного магнітного резонансу C13 [22], яка також дала обнадійливі результати в оцінці динаміки стану пацієнтів на тлі терапії.

Дослідження м'язового біоптату при хворобі Помпе довгий час вважалося основним методом діагностики. Біопсія виявляє вакуольну міопатію лізосомальної природи при визначенні активності кислої фосфатази, при гістоферментативному дослідженні, а також накопичення глікогену. Також виявляються скупчення аутофагованого матеріалу типу ліпофусцину, проліферацію апарату Гольджі або аномальну експресія кавеоліну [23]. Гістологічні зміни в уражених м'язах не завжди відповідають тяжкості захворювання. У зв'язку з особливою чутливістю деяких м'язів до дефіциту GAA, останні можуть бути істотно зменшені в обсязі або навіть повністю атрофуватися [20].

\section{В основі біохімічної діагностики хвороби}

Помпе лежить дослідження активності ферменту GAA за допомогою природних або синтетичних субстратів в кислому середовищі [24]. Сьогодні для проведення реакції практично не використовуються культура фібробластів шкіри, гомогенат м'язового біоптату і очищені лейкоцити. Взаємодія білка GAA з іншими ферментами (наприклад, мальтазоглюкоамілаза - МГА), які наявні в нейтрофілах, може стати причиною хибнонегативних результатів. Тому для діагностики беруть очищені лімфоцити, а в досліджувану середу 
додають інгібітори МГА (акарбозу) [19]. Результати підлягають обов'язковому порівнянні з одночасно отриманими даними контрольної групи.

При дотриманні обов'язкових методологічних умов, ферментативна активність GAA у дитини, що страждає хворобою Помпе, повинна бути нижче 1\%. Як правило, ступінь зниження активності GAA менш виражена у підлітків і дорослих, які страждають на це захворювання. Результати, отримані при флуометрії DBS, виражаються в одиницях пмоль/г.

Для розвитку фенотипових змін необхідно, щоб обидві алелі GAA були носіями патогенної мутації. Патогенність більшості описаних мутацій встановлена на клітинних моделях і обумовлена аномалією зрощування або порушенням біосинтезу білків внаслідок нестабільності РНК месенджерів (РНКм). Сучасні методи молекулярної біології дозволяють передбачити ступінь тяжкості хвороби, яка корелює із залишковим рівнем активності ферменту [20].

\section{Лікування}

Рекомендована пожиттєва ферментозамісна терапія (ФЗТ) рекомбінантної людської кислої а-глюкозидази пацієнтам з підтвердженим діагнозом хвороби Помпе.

Препарат алглюкозидази, рекомбінантний фермент, який синтезується клітинною лінією, отриманої з яєчників китайських хом'ячків. Алглюкозидаза альфа компенсує активність лізосомальної кислої $\alpha$-глюкозидази, що призводить до стабілізації або відновлення функції серцевого і скелетних м'язів (включаючи дихальні м'язи). Препарат добре переноситься, не має виражених побічних ефектів. Показаний для довготривалої ФЗТ у пацієнтів з підтвердженим діагнозом хвороби Помпе різного віку.

Ферментна замісна терапія дозволяє зберегти життя пацієнтам 3 хворобою Помпе, покращує іiі якість та уповільнює прогресування хвороби. Ранній початок терапії дуже важливий, тому що дозволяє домогтися кращих клінічних результатів. Доведено, що застосування ферментної замісної терапії при дитячій формі хвороби зменшує ризик смерті на 99\%, а ризик смерті або необхідності в інвазивній вентиляції легенів - на 92\% [18]. Своєчасне призначення терапії алглюкозидазою альфа викликає зворотний розвиток кардіоміопатії у пацієнтів з дитячою формою хвороби Помпе, покращує показники м'язової сили, рухової активності і стабілізує стан дихальної системи у дітей і дорослих пацієнтів. Терапія алглюкозидазою альфа пацієнтів 3 пізньою формою хвороби уповільнює прогресування хвороби, поліпшуючи стан кістково-м'язової системи і стабілізує стан дихальної системи, підвищує виживаємість пацієнтів і подовжує період їхнього життя до настання необхідності у вентиляції легенів $[13,18,25]$.
При наявності підтвердженого діагнозу хвороби Помпе, незалежно від віку пацієнта, патогенетична терапія алглюкозидазой альфа повинна бути ініційована негайно.

\section{Висновок}

Великий досвід роботи з пацієнтами які страждають на хворобу Помпе дозволяє зробити висновок: незалежно від фенотипної гетерогенності захворювання має єдиний генез. На підставі клінічної картини розрізняють: неонатальную форму, або хворобу Помпе з раннім дебютом, і пізню форму або хворобу Помпе з пізнім дебютом. Дані форми розрізняються поліорганністю ураження, більш тяжким перебігом при інфантильній формі, переважним ураженням м'язів і повільно прогресуючим перебігом при хворобі Помпе з пізнім дебютом. Ключовим методом діагностики хвороби Помпе $\epsilon$ визначення активності ферменту GAA. Підвищення виживання при інфантильних формах на тлі замісної ензимотерапії сприяє детальному вивченню поведінкових і рухових функціональних порушень в рамках даної патології. Завдяки впровадженню в клінічну практику ферментної замісної терапії, ефективність якої сьогодні очевидна, особливо при інфантильних формах, якість життя пацієнтів з хворобою Помпе значно покращилася. Отже, виявлення нових методів лікування $є$ подальшим предметом для дослідження в цій сфері.

\section{References}

1. Raben N, Plotz P, Byrne BJ. (2002) Acid a-glucosidase deficiency (glycogenosis type II, Pompe disease). Curr Mol Med no 2, pp. 66-145.

2. Pompe Center. Molecular aspects: mutations. URL:http://cluster15.erasmusmc.nl/klgn/pompe/ mutations.html.[17.10.2011].

3. Winchester B, Bali D, Bodamer OA, Caillaud C, Christensen E, Cooper A, et al. (2008) Methods for a prompt and reliable laboratory diagnosis of Pompe disease: report from an international consensus meeting. Mol Genet Metab no 93, pp. 81-275.

4. Kishnani PS, Steiner RD, Bali D, Berger K, Byrne BJ, Case LE, et al. (2006) Pompe disease diagnosis and management guideline. Genet Med no 8, pp. 88-267.

5. Chien Y, Lee N, Thurberg B, et al. (2009) Pompe disease in infants: Improving the prognosis by newborn screening and early treatment. Pediatrics. pp. 1116-1125.

6. The official website of Pompe disease in Ukraine Retrieved from https://www.pompe-disease.com. ua/uk/u-ditey-ta-doroslyh [in Ukrainian].

7. American Association of Neuromuscular \& Electrodiagnostic Medicine. (2009) Diagnostic criteria for late-onset (childhood and adult) Pompe disease. Muscle Nerve no 40, pp. 60-149.

8. C. Scriver, A. Beaudet, W. Sly, D. Valle (Eds.), (2001) The metabolic and molecular bases of inherited disease, McGraw-Hill, New York, pp. 3389-3420. 
9. Pompe J.C. (1932) Over idiopathische hypertrofie van het hart. Ned Tijdschr Geneeskd, pp. 11-304.

10. T.M. Ko, W.L. Hwu, Y.W. Lin, L.H. Tseng, H.L. Hwa, T.R. Wang, et al. (1999)Molecular genetic study of Pompe disease in Chinese patients in Taiwan Hum Mutat, 13, pp. 380-384.

11. Barba-Romero M.A., Barrot E., Bautista-Lorite J. et al.( 2012) Clinical guidelines for late-onset Pompe disease. Rev Neurol no 54 (8), pp. 497-507.

12. Fukuda T., Ewan L., Bauer M. et al. (2006) Dysfunction of endocytic and autophagic pathways in a lysosomal storage disease.Ann Neurol no59, pp. 8-70.

13. Cupler E., Berger K., Leshner R. et al. (2012) Consensus treatment recommendations for lateonset Pompe Disease. Muscle and Nerve. no 45(3), pp. 319-333.

14. Llerena J.C., Horovitz D.M., Nagahashi Marie S.K. et al. (2009) The Brazilian Consensus on the Management of Pompe Disease. The Journal of pediatrics. no 155(4 Suppl), pp. 47-56.

15. M.G. Ausems, J. Verbiest, M.P. Hermans, M.A. Kroos, F.A. Beemer, J.H. Wokke, et al. (1999), Frequency of glycogen storage disease type II in The Netherlands: implications for diagnosis and genetic counseling Eur J Hum Genet, no 7, pp. 713-716.

16. Y.H. Chien, S.C. Chiang, X.K. Zhang, J. Keutzer, N.C. Lee, A.C. Huang, et al.Early detection of Pompe disease by newborn screening is feasible: results from the Taiwan screening program Pediatrics, 122 (2008), pp. e39-e45.

17. Kotlukova N.P., Mikhailova S.V., Bukina T.M., Zakharova E.Y. (2012) Infantile Pompe disease: Clinical picture, diagnosis, and treatment. Neuromuscular Diseases. no 4, pp. 66-73 [in Russian].

18. Kishnani P, Corzo D, Leslie N, et al. (2009)Early treatment with alglucosidase alfa prolongs long term survival of infants with Pompe disease. Pediatr Res. no 66(3), pp. 35-329.

19. Hagemans M, Winkel, Hop W, et al. (2005) Disease severity in children and adults with Pompe disease related to age and disease duration. Neurology. pp. 2139-2141.

20. Desnuelle C. (2012) Pozdnjaja forma bolezni Pompe: diagnosticheskie i terapevticheskie podhody Nervno-myshechnye bolezni. [Late form of Pompe disease: diagnostic and therapeutic approaches.] Neuromuscular diseases. no 3, pp. 20-32 [in Russian].

21. Carlier R.Y., Laforet P., Wary C. et al. (2011) Whole-body muscle MRI in 20 patients suffering from late onset Pompe disease: Involvement patterns. Neuromuscul Disord pp. 9-791.

22. Wary C., Laforêt P., Eymard B. et al. (2003) Evaluation of muscle glycogen content by 13C NMR spectroscopy in adult-onset acid maltase deficiency. Neuromuscul Disord pp. 545-53.

23. Nascimbeni A.C., Fanin M., Tasca E. et al. (2008) Molecular pathology and enzyme processing in various phenotypes of acid maltase deficiency. Neurology no 70(8) pp. 617-26.
24. Van der Ploeg A.T., Reuser A. (2008) Pompe’s disease. Lancet. pp. $53-372$.

25. Winkel L, Hagemans M, van Doorn P, et al. (2005) The natural course of non-classic Pompe's disease; a review of 225 published cases. J Neurol. pp. $84-875$.

\section{Болезнь Помпе}

\section{Свиридова Н.К.}

д.мед.н., профессор, зав. кафедры неврологии и рефлексотерапии Национальной медицинской академии последипломного образования имени П.Л. Шупика

\section{Свистун В.Ю.}

клинический ординатор кафедры неврологии и рефлексотерапии Национальной медицинской академии последипломного образования имени П.Л. Шупика

\section{Елизарова О.В.}

интерн кафедры неврологии и рефлексотерапии Национальной медицинской академии последипломного образования имени П.Л. Шупика

\section{Резюме}

Заболевания Помпе является редкой, прогрессирующей болезнью, в основе патогенеза которой лежит избыточное накопление гликогена лизосомами в результате мутации гена GAA и потери активности фермента кислой $а$-глюкозидазы. Преимущественное накопление гликогена отмечено в поперечно-полосатых мышцах, но в разной степени может проявляться и в других органах и тканях, включая сердечную мышцу, печень, нервную систему. Тип наследования - аутосомно-рецессивный. В клинической практике выявления характерных симптомов позволяют своевременно заподозрить болезнь Помпе. Достаточная информированность и настороженность врача по болезни Помпе, при совокупности характерных симптомов облегчает диагностику. РТ в Т1-режиме позволяет легко оценить трофику мышц и выявить специфические области фиброзно-жировой дегенерации, что характерно для мышечной дистрофии. Исследование мышечного биоптата при болезни Помпе обнаруживает вакуольная миопатии лизосомальной природы при определении активности кислой фосфатазы, при гистоферментативному исследовании, а также накопление гликогена. В основе биохимической диагностики болезни Помпе лежит исследование активности фермента GAA с помощью природных или синтетических субстратов в кислой среде. Современные методы молекулярной биологии позволяют предположить степень тяжести болезни, коррелирует с остаточным уровнем активности фермента. Рекомендуемая пожизненная ферментозамисна терапия рекомбинантной человеческой кислой $\alpha$-глюкозидазы пациентам с подтвержденным диагнозом болезни Помпе. Ферментная заместительная терапия позволяет 
сохранить жизнь пациентам с болезнью Помпе, улучшает ее качество и замедляет прогрессирование болезни. Раннее начало терапии очень важен, так как позволяет добиться лучших клинических результатов. Доказано, что применение ферментной заместительной терапии при детской форме болезни уменьшает риск смерти на 99\%, а риск смерти или необходимости в инвазивной вентиляции легких - на 92\%. При наличии подтвержденного диагноза болезни Помпе, независимо от возраста пациента, патогенетическая терапия алглюкозидазой альфа должна быть инициирована немедленно.

Ключевые слова: болезнь Помпе, дефицит кислой мальтазы (AMD), нарушения накопления гликогена (GSD) типа II, гликогеноз II типа, дефицит альфа-глюкозидазы.

\section{Pompe disease}

\section{Svyrydova $\mathbf{N}$.}

Department of Neurology and Reflexology, Shupyk National Medical Academy of Postgraduate Education

\section{Svystun V.}

Department of Neurology and Reflexology, Shupyk National Medical Academy of Postgraduate Education

\section{Yelizarova 0.}

Department of Neurology and Reflexology, Shupyk National Medical Academy of Postgraduate Education

\section{Resume}

Pompe disease is a rare, progressive disease, the basis of which is the pathogenesis of excessive accumulation of glycogen by lysosomes due to mutation of the GAA gene and loss of activity of the enzyme acidic $\alpha$-glucosidase. Preferred accumulation of glycogen is noted in cross-linked muscles, but can vary in degrees in other organs and tissues, including cardiac muscle, liver, nervous system. The type of inheritance is autosomal recessive. In clinical practice, the detection of characteristic symptoms allows you to timely suspect Pompe disease. Sufficient awareness and alertness of the doctor about Pompe's disease, with a combination of characteristic symptoms, facilitates diagnosis. RT in T1 mode makes it easy to assess muscle tropism and to identify specific areas of fibrous-fat degeneration, which is characteristic of muscular dystrophy. The study of muscular biopsy in Pompe disease reveals a vacuated myopathy of lysosomal nature in determining the activity of acid phosphatase, in a histo-enzymatic study, as well as glycogen accumulation. The basis of the biochemical diagnosis of Pompe disease is the study of the activity of the enzyme GAA with the help of natural or synthetic substrates in the acidic medium. Modern molecular biology techniques can predict the severity of the disease, which correlates with the residual activity of the enzyme. Life-long enzyme replacement therapy for recombinant human acid $\alpha$-glucosidase in patients with a confirmed diagnosis of Pompe disease is recommended. Enzyme replacement therapy helps preserve life for patients with Pompe disease, improves its quality and slows the progression of the disease. The early start of therapy is very important, because it allows you to achieve the best clinical results. The use of enzyme replacement therapy in childhood disease has been shown to reduce the risk of death by $99 \%$, and the risk of death or need for invasive ventilation is $92 \%$. In the presence of a confirmed diagnosis of Pompe disease, regardless of the age of the patient, pathogenetic therapy with alglucosidase alfa should be initiated immediately.

Key words: Pompe disease, Sulfur Maltase deficiency (AMD), Type II glycogen accumulation disorder (GSD), Type II glycogenosis, Alphaglucosidase deficiency. 